\title{
Population biology of Durvillaea antarctica and Lessonia nigrescens (Phaeophyta) on the rocky shores of southern Chile
}

\author{
Renato Westermeier ${ }^{1}$, Dieter G. Müller ${ }^{2}$, Iván Gómez ${ }^{1}$, Pedro Rivera $^{1}$, Hedwig Wenzel $^{1}$ \\ ${ }^{1}$ Instituto de Botánica, Facultad de Ciencias, Universidad Austral de Chile, Casilla 567, Valdivia, Chile \\ ${ }^{2}$ Fakultät für Biologie der Universität Konstanz, D-78434 Konstanz, Germany
}

\begin{abstract}
The Lessonia nigrescens-Durvillaea antarctica belt is a characteristic feature of the lower intertidal zone along the Chilean coast. This study describes the dynamics of the Lessonia-Durvillaea assemblage in an exposed locality of southern Chile. Abundance, spatial and temporal distribution, reproductive periods and response to experimental pruning were quantified. The results revealed differences in population dynamics between species. L. nigrescens had low recruitment, but a longer life expectancy. In contrast, $D$. antarctica had great temporal fluctuations in abundance, which were associated to massive recruitment during the warmer seasons. It occupied zones where old $L$. nigrescens individuals were dislodged by wave action. Replacement of $D$. antarctica by $L$. nigrescens was not seen. Regeneration from pruned plants of the 2 species was evident during the first months, but subsequently, deterioration of the regenerated parts was seen, leading to the degeneration and detachment of the whole plant. Thus, for management plans, the total removal of old individuals would be preferable.
\end{abstract}

KEY WORDS: Population biology $\cdot$ Seaweed $\cdot$ Durvillaea $\cdot$ Lessonia

\section{INTRODUCTION}

Durvillaea antarctica (Cham.) Hariot and Lessonia nigrescens Bory form a conspicuous belt in a lower intertidal rocky shore of the Chilean coast southward from $30^{\circ} \mathrm{S}$ (Guiler 1959, Westermeier 1980, Santelices 1981, Westermeier \& Rivera 1986).

Comparative studies in central Chile (Santelices et al. 1980, Ojeda \& Santelices 1984) have shown that the competitive interaction of both species seems to follow the community structure model proposed by Connell (1975) and Menge \& Sutherland (1976), with Lessonia nigrescens persisting in areas of high wave exposure due its morphological adaptations while Durvillaea antarctica persists because of its high reproductive rate, rapid growth, and rapid replacement. The population ecology of these species is not known for southern Chilean communities, nevertheless, some data on geographical distribution revealed that the Lessonia-
Durvillaea belt suffers local variations, mainly in its vertical limits (Westermeier \& Rivera 1986).

During recent years, humans have heavily exploited populations of Durvillaea antarctica and Lessonia nigrescens in accessible areas (Santelices et al. 1980 , Westermeier 1987, Castilla \& Bustamante 1989). In 1989 , the annual landing of $L$. nigrescens reached $62723 \mathrm{t}$, harvested mainly in central and northern Chile, while the annual harvest of $D$. antarctica reached $1040 \mathrm{t}$ (Sernap 1989).

These facts highlight the need to understand the population dynamics of these species from southern Chile in order to provide information for management programs. With this in mind, our study provides quantitative data on spatial and temporal changes in distribution and abundance, and reproductive phenology, as well as morphology. Finally, we report on the effect of experimental pruning on regeneration and survival of plants. 


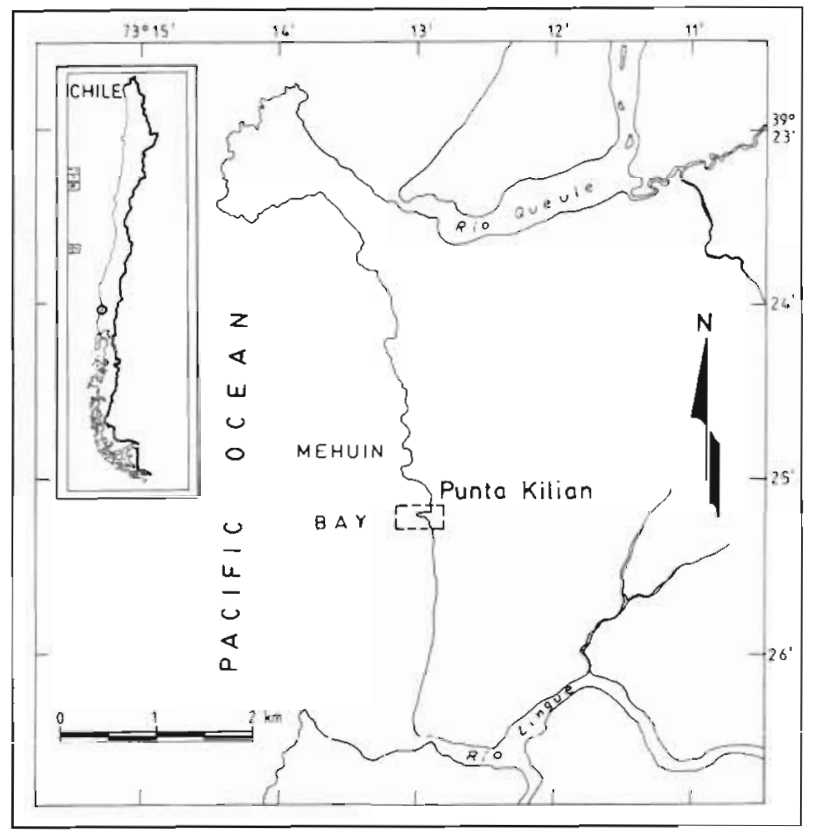

Fig. 1. Mehuin Bay in southern Chile showing the Punta Kilian site

\section{MATERIAL AND METHODS}

Abundance and distribution patterns. The study was conducted between April 1985 and September 1987 along the exposed rocky shore of Mehuin (Punta Kilian, $39^{\circ} 24^{\prime} \mathrm{S}, 73^{\circ} 14^{\prime} \mathrm{W}$ ). This area (Fig. 1) has been protected from human interference since 1978.

To evaluate the temporal and spatial distribution of Lessonia nigrescens and Durvillaea antarctica kelps, 2 slightly inclined platforms of $42 \mathrm{~m}^{2}$, which were exposed to different wave impact, were selected. These areas were divided into 42 permanent $1 \mathrm{~m}^{2}$ quadrats and the total number of plants within every quadrat was monitored seasonally. Evaluation of wave force was indirectly made by measurement of the erosion of plaster of Paris blocks, according to the method described by Doty (1971).

Reproductive phenology. Studies on reproductive state of both Lessonia nigrescens and Durvillaea antarctica were carried out monthly taking random samples from a less exposed platform. Data on total density of plants inside the platform were also taken, which were related to the percentage of reproductive individuals. No sampling in the more exposed area was performed because initial evaluations in Punta Kilian indicated negligible changes in reproductive phenology attributable to wave exposure. The determination of reproductive maturity was done by examination of sections of the sori ( $L$. nigrescens) and conceptacles ( $D$, antarctica).
Morphometric relationships and size structure. To determine the temporal changes in morphometric parameters, 20 plants from each Lessonia nigrescens and Durvillaea antarctica belt were marked. Because of the low life expectancy of the individuals that inhabit more exposed sites, the marked plants were selected from the less exposed platform. Holdfast diameter, stipe length and frond size were measured throughout the study period. Seasonal determinations of dry weight were performed from 15 individual samples of the 2 species from the same site (less exposed). Dry weight was determined separately for holdfast, stipe and fronds. These measurements were made to provide regression data (Sokal \& Rohlf 1969).

To evaluate temporal incidence of the different size classes, monthly changes in the abundance of Lessonia nigrescens and Durvillaea antarctica were determined based on 3 size categories and using the maximum holdfast diameter.

Experimental pruning regeneration and mortality. Considering that Lessonia nigrescens is an alga with multiple stipes arising from a solid holdfast, while Durvillaea antarctica has only one, we designed an experiment evaluating the comparative capacity of regeneration of the stipes after an experimental cutting.

Fig. 2 shows the harvesting scheme. Durvillaea antarctica was cut in the transition zone between stipe and leafy frond, whereas Lessonia nigrescens was pruned at the first dichotomy of the stipe. This experiment was carried out at different seasons with groups of 20 plants from a site with moderate wave impact. Similar numbers of plants were used as a control group. Regeneration was evaluated by detection of

$$
\begin{array}{ll}
\text { L. nigrescens } & \text { D. antarctico }
\end{array}
$$

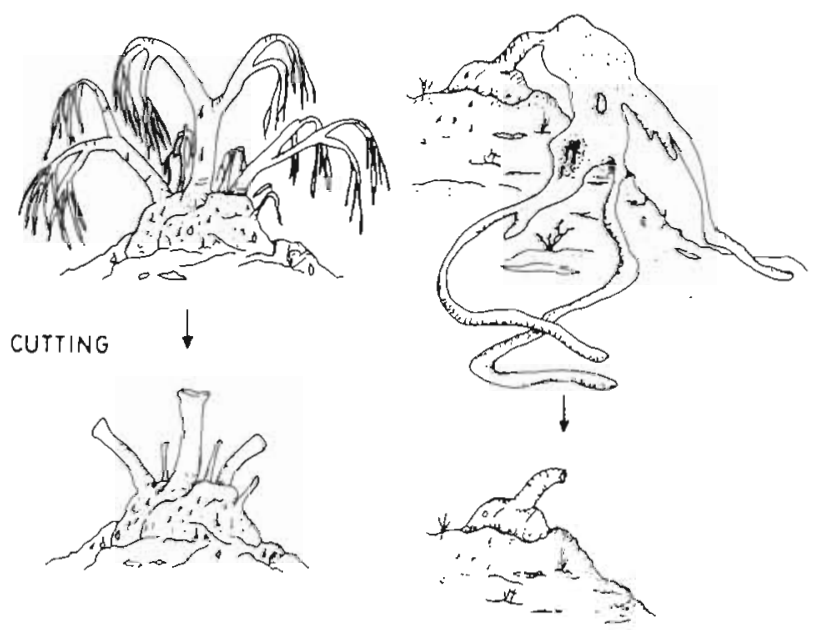

Fig. 2. Lessonia nigrescens, Durvillaea antarctica. Gieneral morphology of 2 kelps showing the experimental pruning 
shoots on the pruned stipes and monthly changes in holdfast diameter and length of pruned stipes were recorded. Additionally, 30 young plants of both species from the same area were used for the evaluation of mortality and life expectancy

\section{RESULTS}

On the more exposed rocky platform, Durvillaea antarctica showed a strong seasonality, with greater abundance during January and May 1987, reaching maximum values between 26 and 30 plants $\mathrm{m}^{-2}$ (Fig. 3). Nevertheless, D. antarctica was absent from most quadrats. In contrast Lessonia nigrescens ex-
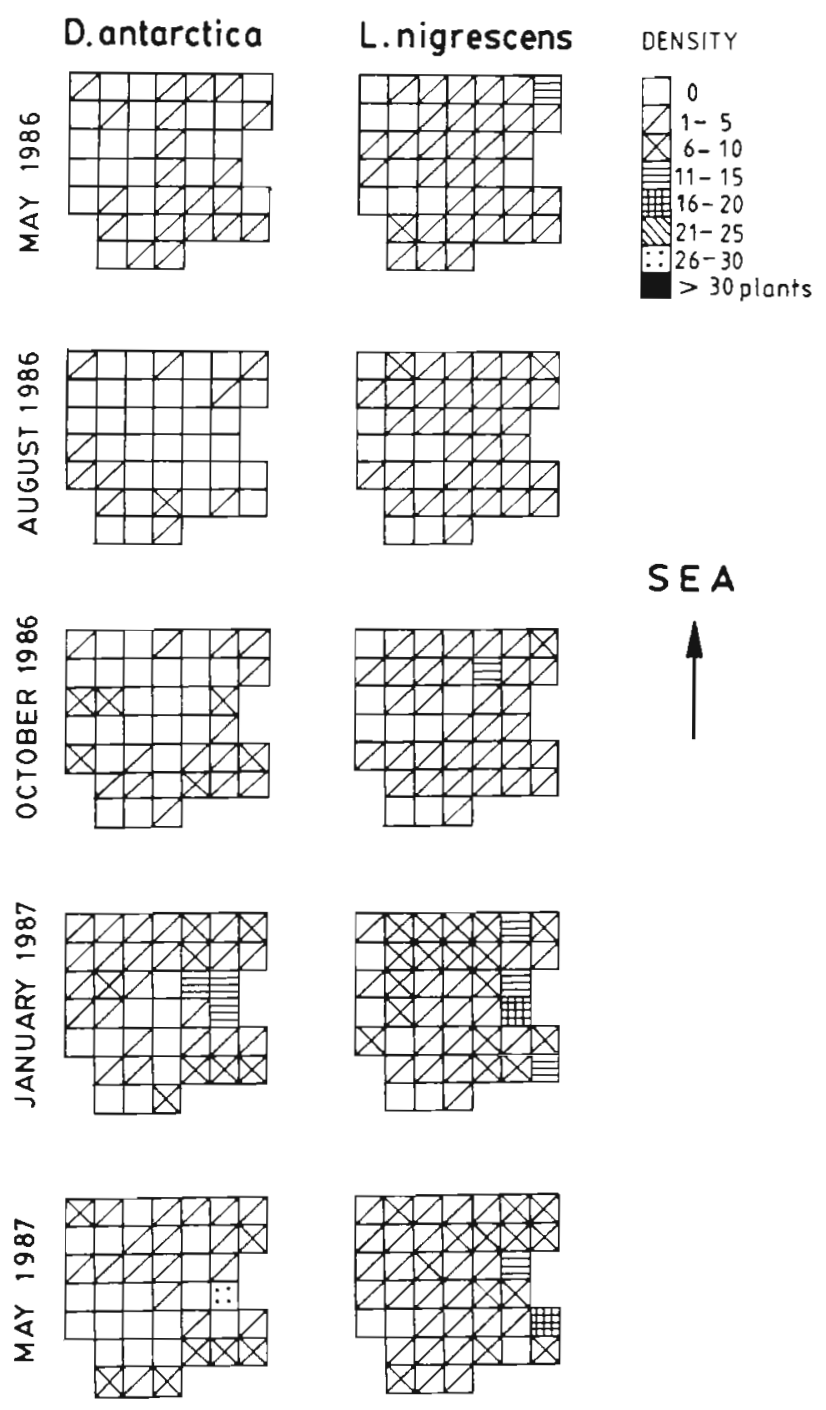

Fig. 3. Durvillaea antarctica, Lessonia nigrescens. Seasonal and spatial variations in abundance of kelp on the more exposed rocky platform
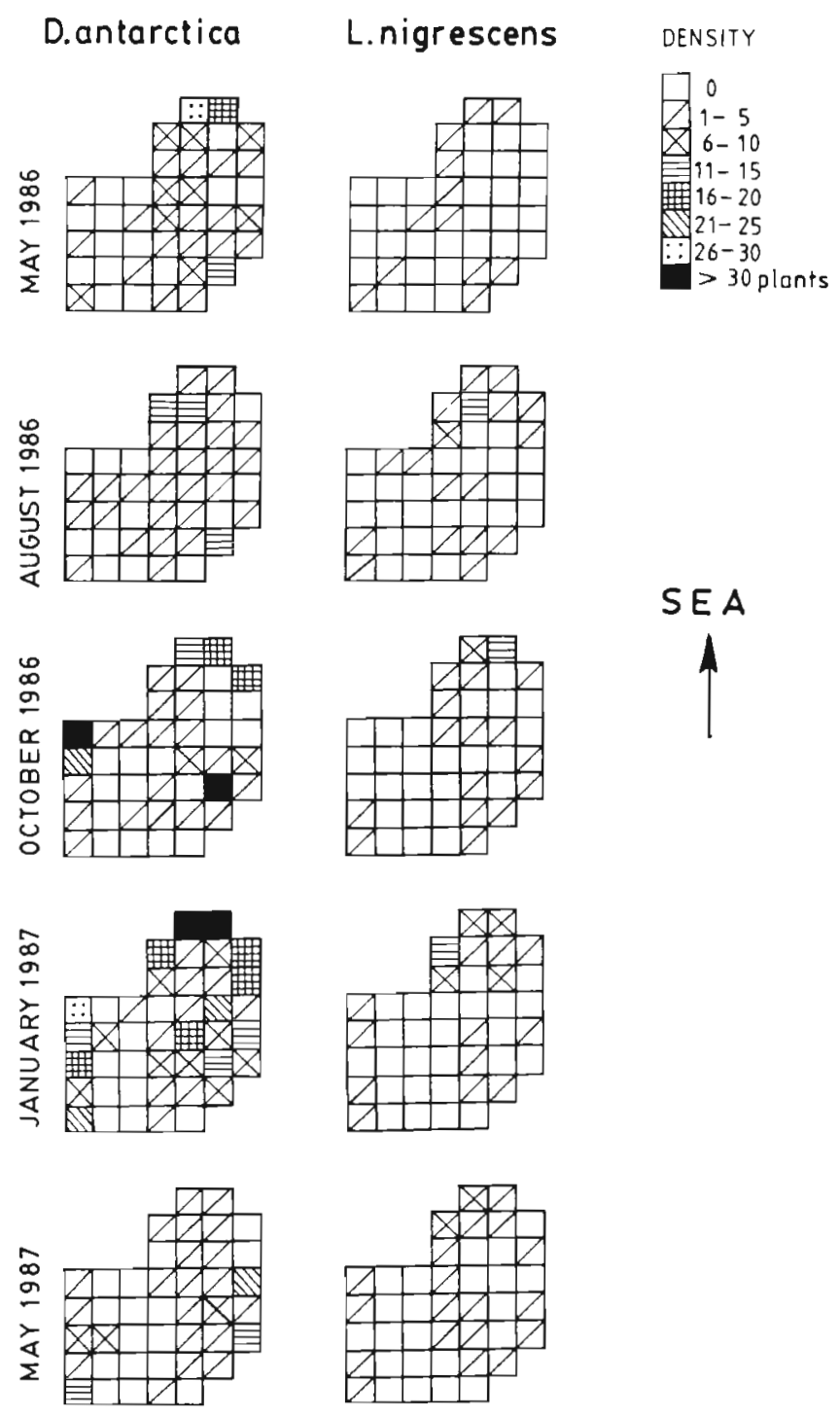

Fig. 4. Durvillaea antarctica, Lessonia nigrescens. Seasonal and spatial variations in abundance of kelp on the less exposed platform

hibited a more stable temporal abundance, which increased during January and May 1987 to values close to 20 plants $\mathrm{m}^{-2}$. In this area $L$. nigrescens dominated and showed a more homogeneous cover than $D$. antarctica.

Durvillaea antarctica was more abundant in the less exposed site (Fig. 4). This species reached values greater than 30 plants $\mathrm{m}^{-2}$ and extended its distribution limit during October 1986 and January 1987, occurring principally in the periphery of the site. Lessonia nigrescens also occurred in the marginal areas, but did not enlarge its range. Its abundance was reduced, with maximal values of 11 and 15 plants $\mathrm{m}^{-2}$ in January 1987. 


\section{Relationship between abundance and reproductive phenology}

Durvillaea antarctica showed a strong seasonal pattern of abundance, with 2 peaks of greater abundance, first in summer-autumn 1986 and next during summer 1986-1987 (Fig. 5). In this species, the number of reproductive plants had a high negative correlation $(\mathrm{r}=-0.82, \mathrm{p}<0.05\}$ with abundance. Apparently, the high recruitment rates seen in $D$. antarctica included a great number of young individuals, which do not share in reproduction. On the other hand, abundance of Lessonia nigrescens fluctuated less and there was no significant relationship with reproduction $(r=-0.11$, $\mathrm{p}>0.05)$.

\section{Morphometric parameters}

Morphologically, Lessonia nigrescens is well adapted to high wave exposure. Its solid holdfast, strong stipes, and small dichotomously branched fronds show high resistance to mechanical forces (Köehl
1986). In contrast, in Durvillaea antarctica, the large proliferate frond is connected to a smaller holdfast by a short, slender stipe. This was further confirmed by the analysis of temporal variation in the morphometric parameters (Fig. 6), frond length being the more variable morphological characteristic. In $D$. antarctica, fronds show a strong variation between individuals $(15$ to $230 \mathrm{~cm}$ ) and between months throughout the year, but no clear seasonal pattern was found. Probably, the morphological changes of the frond in $D$. antarctica are regulated by meristoderm activity versus destruction of the apical zones of the frond which appears to be caused by multiple agents. On the other hand, L. nigrescens attains a maximum frond length of $50 \mathrm{~cm}$ with lower monthly variations. In May and June 1985, frond length of $L$. nigrescens declined, coinciding with zoospore release. This suggests that morphological shape could be related to reproductive siate at some times.

The regression analysis (Table 1 ) indicates that in Durvillaea antarctica there is a high correlation between frond weight and total weight of the plant $(\mathrm{r}=$ $0.99, p<0.05$ ). Likewise, a significant direct relation-

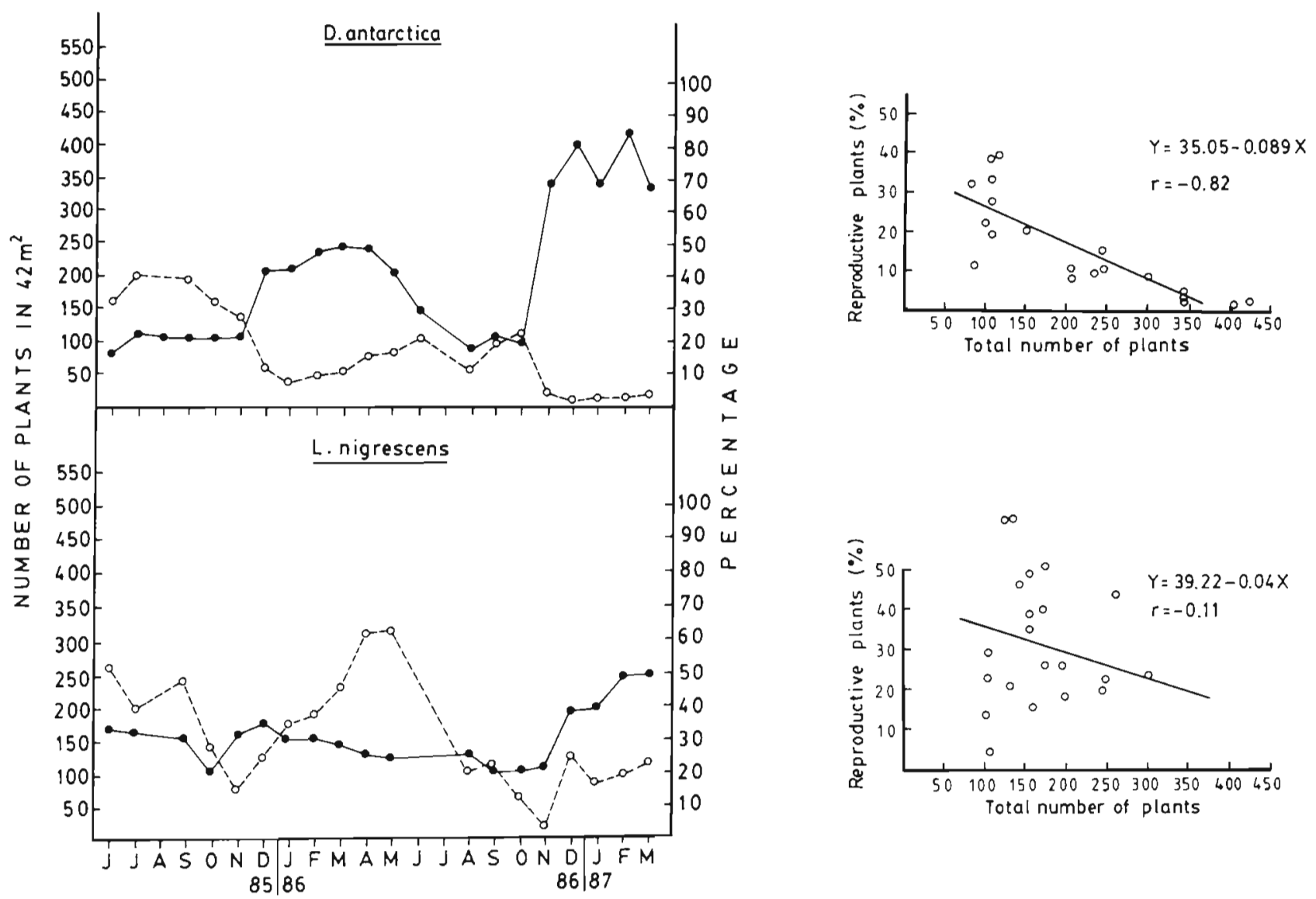

Fig. 5. Durvillaea antarctica, Lessonia nigrescens. Monthly changes in total number of plants (๑) and relative percentage of reproductive plants $(0)$, as well as the statistical relationship between plant density and reproductive percentage 


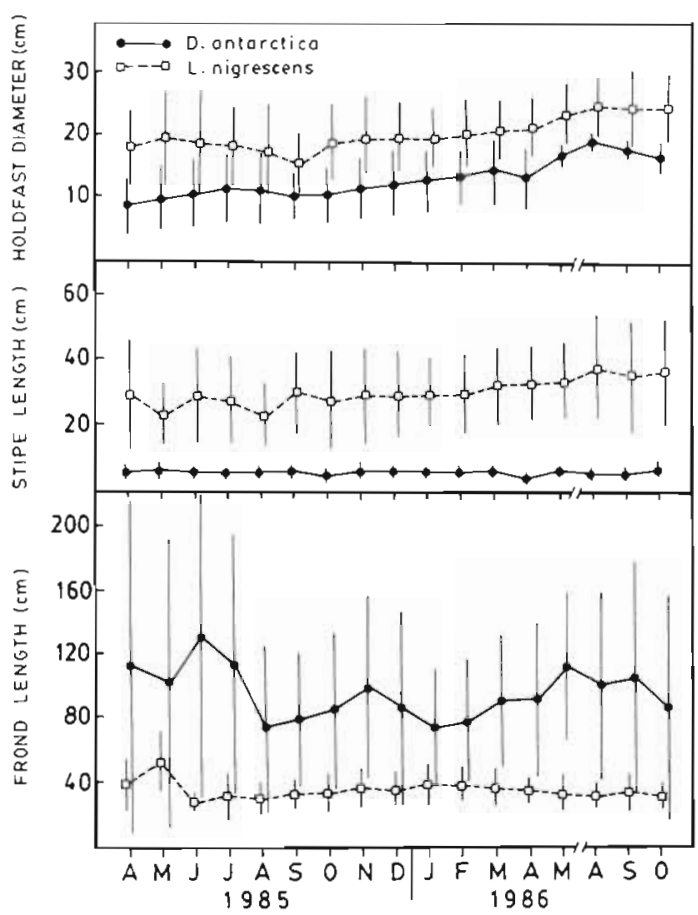

Fig. 6. Durvillaea antarctica, Lessonia nigrescens. Monthly changes in morphometric characteristics of 2 species of kelp

Table 1. Durvillaea antarctica. Relationship between different morphometric parameters. $\mathrm{n}=84$

\begin{tabular}{|c|c|c|}
\hline $\begin{array}{l}\text { Variables } \\
y \text { vs } x\end{array}$ & Equation & $\begin{array}{l}\text { Correlation } \\
\text { coefficient }(r)\end{array}$ \\
\hline \multicolumn{3}{|l|}{ Frond weight vs: } \\
\hline Total weight & $y=-16.94+0.94 x$ & $0.99 \cdot$ \\
\hline \multicolumn{3}{|l|}{ Holdfast weight vs: } \\
\hline Total weight & $y=8.53+0.04 x$ & $0.83 \cdots$ \\
\hline \multicolumn{3}{|c|}{ Holdfast diameter vs: } \\
\hline Holdfast weight & $y=6.25+0.17 x$ & $0.73^{\circ}$ \\
\hline Total weight & $y=7.48+0.008 x$ & $0.70^{\circ}$ \\
\hline Frond weight & $y=7.66+0.009 x$ & $0.69^{\circ}$ \\
\hline Stipe diameter & $y=3.47+3.35 x$ & $0.58 \cdots$ \\
\hline Frond length & $y=5.97+0.02 x$ & $0.55^{\cdots}$ \\
\hline \multicolumn{3}{|l|}{ Frond length vs: } \\
\hline Total weight & $y=103.49+0.20 x$ & $0.70^{\circ}$ \\
\hline Frond weight & $y=107.32+0.21 x$ & $0.70^{\circ}$ \\
\hline \multicolumn{3}{|l|}{ Stipe diameter vs: } \\
\hline Frond weight & $y=1.59+0.001 x$ & $0.48^{\cdots}$ \\
\hline Total weight & $y=1.57+0.001 x$ & $0.48^{\circ}$ \\
\hline Frond length & $y=1.42+0.0026 x$ & $0.36^{\circ}$ \\
\hline Stipe length & $y=1.51+0.041 x$ & $0.20^{\text {ns }}$ \\
\hline \multicolumn{3}{|l|}{ Stipe length vs: } \\
\hline Stipe diameter & $y=6.06+0.18 x$ & $0.24^{\circ}$ \\
\hline
\end{tabular}

Table 2. Lessonı nigrescens. Relationship between different morphometric parameters. $n=83$

\begin{tabular}{|c|c|c|}
\hline $\begin{array}{l}\text { Variables } \\
y \text { vs } x\end{array}$ & Equation & $\begin{array}{c}\text { Correlation } \\
\text { coefficlent }\{I\}\end{array}$ \\
\hline \multicolumn{3}{|l|}{ Frond weight vs: } \\
\hline Total weight & $y=7.31+0.29 x$ & $0.95 \cdots$ \\
\hline \multicolumn{3}{|l|}{ Holdfast weight vs: } \\
\hline Total weight & $y=8.84+0.20 x$ & $0.88^{\cdots}$ \\
\hline Stipe weight & $y=20.88+0.39 x$ & $0.86^{\cdots}$ \\
\hline Frond weight & $y=19.02+0.59 x$ & $0.79^{*}$ \\
\hline Number of stipes & $y=51.79+2.48 x$ & $0.21^{\bullet}$ \\
\hline \multicolumn{3}{|l|}{ Stipe weight vs: } \\
\hline Frond weight & $y=5.47+1.42 x$ & $0.87^{\cdots}$ \\
\hline \multicolumn{3}{|l|}{ Holdfast diameter vs: } \\
\hline Total weight & $y=9.71+0.008 x$ & $0.81^{\cdots}$ \\
\hline Holdfast weight & $y=10.03+0.03 x$ & $0.76^{\cdots}$ \\
\hline Stipe length & $y=7.90+0.31 x$ & $0.56^{\circ}$ \\
\hline Frond length & $y=7.79+0.16 x$ & $0.47^{\cdots}$ \\
\hline Number of stipes & $y=8.82+0.21 x$ & $0.44^{\cdots}$ \\
\hline \multicolumn{3}{|l|}{ Frond length vs: } \\
\hline Frond weight & $y=28.41+0.037 x$ & $0.41 \cdots$ \\
\hline \multicolumn{3}{|l|}{ Number of stipes vs: } \\
\hline Total weight & $y=18.40+0.006 x$ & $0.32^{\circ}$ \\
\hline Frond length & $y=23.56+0.06 x$ & $-0.085^{\mathrm{ns}}$ \\
\hline Stipe length & $y=20.84+0.03 x$ & $0.031^{\mathrm{ns}}$ \\
\hline
\end{tabular}

ship between the holdfast weight and total weight was found $(r=0.83)$. The other morphometric characteristics show lower correlation coefficients. A similar pattern was shown by Lessonia nigrescens (Table 2), with the variations of frond weight and holdfast weight being directly proportional to the total plant weight ( $r=$ 0.95 and $r=0.88, p<0.05)$. The stipes of L. nigrescens are strongly integrated in the morphology of the thallus, and their weight correlates significantly with the frond weight and the holdfast weight ( $r=0.87$ and $r=0.86, p<0.05$, respectively). It must be emphasized that the number of stipes showed little statistical relationship with the remaining morphometric parameters, the highest correlation being the holdfast diameter $(r=0.44)$.

\section{Monthly changes in holdfast size classes}

Temporal changes in size structure (Fig. 7) indicate that the smaller individuals have a high incidence in the population. In Durvillaea antarctica, plants larger than $8 \mathrm{~cm}$ exhibit a density of up to 40 plants on $42 \mathrm{~m}^{2}$; nevertheless, throughout the study period, no significant variations were seen. The size class $<8 \mathrm{~cm}$ 


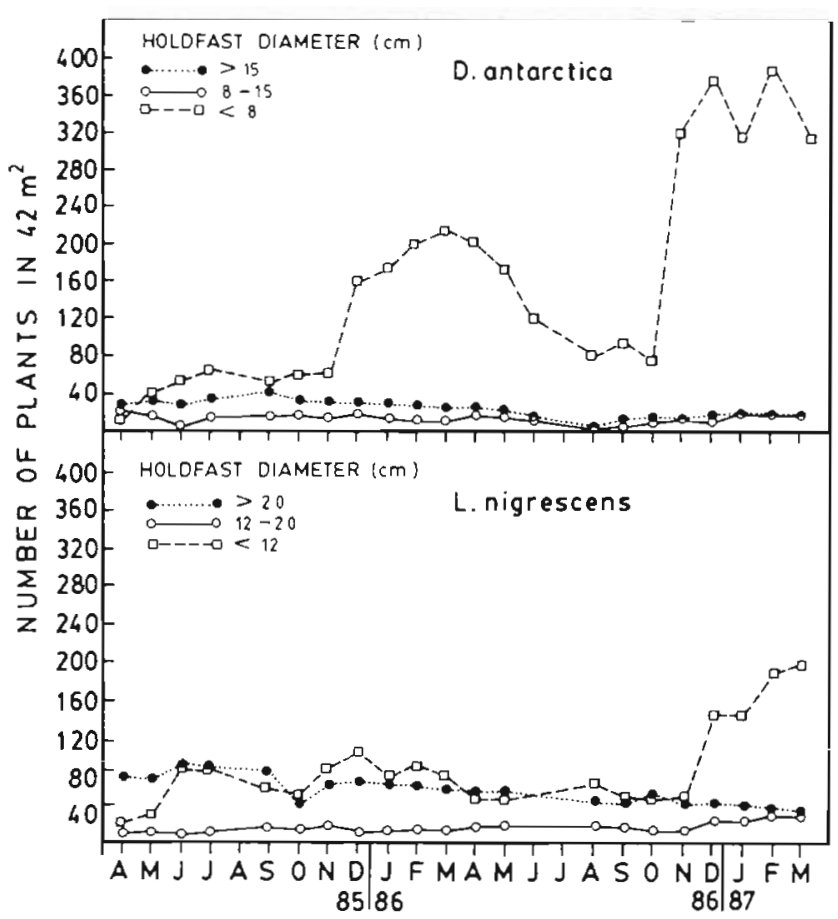

Fig. 7. Durvillaea antarctica, Lessonia nigrescens. Monthly changes in density for 3 size classes of kelp. Intervals correspond to maximum holdfast diameter

showed clear predominance, with a peak in summerautumn 1986 and a peak in summer 1987. This is associated with massive recruitment, reaching an abundance close to 390 plants on $42 \mathrm{~m}^{2}$ at the end of the study. Unlike $D$. antarctica, the size structure of Lessonia nigrescens was more homogenous during the study. It was seen that size classes ranging between 12 and $20 \mathrm{~cm}$ were highly represented, reaching a maximum abundance in June 1985 (autumn) of 83 plants on $42 \mathrm{~m}^{2}$. The size class $<12 \mathrm{~cm}$ showed small seasonal variation during the large part of the study, but towards the end, the number of young plants increased, reaching a maximum value of 190 plants on $42 \mathrm{~m}^{2}$.

\section{Experimental pruning and mortality}

It was clear that Durvillaea antarctica undergoes the more drastic mortality after pruning, higher than $73 \%$ in the 3 seasons (Fig. 8). In contrast, most Lessonia nigrescens mortality occurred in autumn and spring and was lower than $30 \%$. The control also showed a mortality level similar to pruned plants. Regeneration was very high $30 \mathrm{~d}$ after pruning, mainly in $D$, antarctica. In autumn it reached $100 \%$ of plants regenerated, while $L$. nigrescens in the same time did not show regeneration. Later, in winter, the regenerative capacity decreased in both $D$. antarctica and $L$. nigrescens. Finally, it was observed that regenerated shoots deteriorated and the plant began to detach.

\section{DISCUSSION}

The results of the present study in southern Chile indicate that the distributions of Durvillaea antarctica and Lessonia nigrescens are similar to those in central Chile. Although there was some overlap during the warmer months, a different distribution within the sites was seen. In this sense, $L$. nigrescens occupies the wave-battered sectors of the platforms, with densities of more than 20 plants $\mathrm{m}^{-2}$ in some areas. Santelices (1981) postulates that at exposed intertidal levels, distribution patterns are mainly determined by the morphology of the algae. The morphological differences between the studied species consitute a major regulatory factor for the structure and dynamic of the Lessonia-Durvillaea belt. In Mehuin, D. antarctica occurs preferentialiy on the periphery of less exposed rocks, which is consistent with the results of Hay (1977) for $D$. antarctica from New Zealand. In contrast, $L$. nigrescens, with a morphology much better suited to wave impact, is most abundant in exposed areas. The distribution limits are more stable in $L$. nigrescens due to its lower recruitment and mortality, while in $D$.

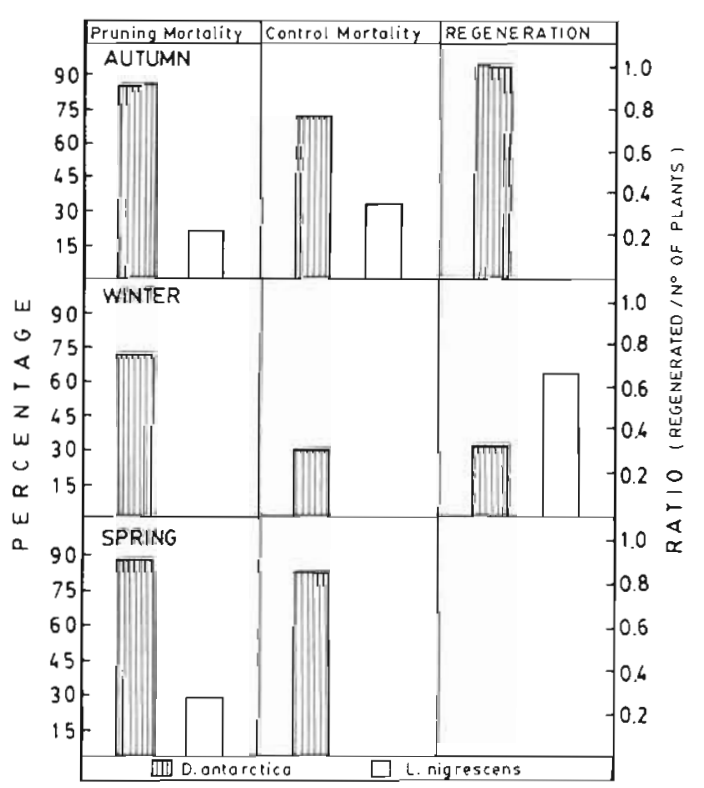

Fig. 8. Response of Durvillaea antarctica and Lessonia nigrescens to experimental cutting. Bars represent values of mortality and regeneration after 5 mo. Regeneration was calculated as regenerated plants divided by the total number of plants 
antarctica, the abundance is more variable, expanding its lower limit during summer (the period with lowest wave action).

Population structure of Durvillaea antarctica is determined principally by young individuals (in this study determined by holdfast diameter classes), which constitute more than $80 \%$ of the population during summer-autumn. This pattern suggests the existence of recruitment processes associated with plant density. For example, Cheshire \& Hallam (1988a) postulate that in $D$. antarctica reproductive potential must be stored in an inflated density of young plants until a gap in the canopy allows fast growth. Lessonia nigrescens, in contrast, presents a more stable population structure, as only 1 massive recruitment event occurred (summer 1987). According to Cheshire \& Hallam (1989), the alteration of generations (heteromorphic life cycle) occurring in laminarian algae versus its absence in fucalean algae determines the differences in population structure. Probably, this factor could explain the differences found in the Lessonia-Durvillaea assemblage from Mehuin. In central Chile, Santelices \& Ojeda (1984) relate the low recruitment rate of $L$. nigrescens to space-dependent factors, indicating that after removal of adult plants, high recruitment could be expected. This should be associated with age composition of the population. Thus, taking into account the analysis by Cheshire \& Hallam (1989), the more exposed habitats, common in central Chile, contain a high number of low vitality, young plants and the population has high recruitment rates. On the other hand, the southern Chilean populations are dominated by old individuals with high vitality and, therefore, decreased turnover rates.

Wave action has been frequently recognized as a major factor regulating the morphology and life span of these kelps (South \& Hay 1974. Santelices et al. 1980, Köehl 1986, Cheshire \& Hallam 1988b). This effect should be seen in a seasonal pattern. Nevertheless, no temporal variation in morphological characteristics was found in our study. Holdfast and stipes are not subject to temporal changes and frond length does not show a clear seasonal pattern. Seemingly, other factors such as extreme desiccation (Schonbeck \& Norton 1978, Druehl \& Green 1982, Hawkins \& Hartnoll 1985, Cheshire \& Hallam 1988a, b) or mechanical damage during low tide could cause losses in the distal parts of the thallus. Another alternative explanation comes from recent studies on infection by slime moulds. This fact has been reported in Durvillaea antarctica in southern Chile (Aguilera et al. 1988) and D. potatorum from Australia (Cheshire \& Hallam 1988b). Since this agent causes necrosis in distinct zones of the thallus, there may be a relationship with population mortality or at least with plant morphology.
Further experimental studies are necessary. On the other hand, morphological changes in Lessonia nigrescens can be caused by the limpet Scurria scurra According to Santelices et al. (1980) and Muñoz \& Santelices (1989), this organism has a pruning effect, mainly on the largest stipes, preventing detachment by wave shock. The Lessonia-Scurria interaction was common at our sites, but not evaluated

Several workers have discussed the influence of human predation on the population dynamics of Lessonia nigrescens and Durvillaea antarctica. Santelices et al. (1980) postulate that human interference is not a predominant selective factor in the Lessonia-Durvillaea belt at exposed areas, refuting Guiler's (1959) prediction that removal of $D$. antarctica by algal collectors prevents the competitive displacement of $L$. nigrescens. Castilla \& Bustamante (1989) and Bustamante \& Castilla (1990) demonstrated that the standing crop of $D$. antarctica in central Chile can be reduced by intensive human activity. Likewise, in southern Chile, Westermeier \& Chacana (unpubl. data) compared 2 areas with different levels of human access and found the absence of $D$. antarctica in the sector which is open to humans. However, no one has yet measured the effects of the biomass reduction of $D$. antarctica on the biomass of $L$. nigrescens at those localities. Thus, although there seems to be no question of the effect of human predation on the population dynamics of $D$. antarctica, we still lack data on the direct or indirect effects of such predation pressure on the population of $L$. nigrescens.

Our pruning data are in agreement with those reported by Santelices et al. (1980), who observed initiation of fronds, mainly in Lessonia nigrescens. However this did not happen in all stipes, and the plants later detached. Likewise, Durvillaea antarctica responded positively to cutting, with numerous bladeshoots arising from the stipe. Nevertheless, after 3 mo they began to deteriorate and, like in L. nigrescens, caused the death of the plant. Although high mortality after pruning was evident, losses of the control plants were also considerable, mainly when the environmental conditions were more extreme. This confirms the results of Santelices et al. (1980), who claim that human action is not a determinant in exposed areas. Observations comparing the traditional harvesting technique employed by algal collectors and the cutting model applied in our study indicate the suitability of the removal of entire plants including the holdfast. Thus the harvesting strategy should consist of total removal of adult individuals after their reproductive period, winter-spring for $L$. nigrescens, and summer for $D$. antarctica. In this way, plants harvested are those strongly subject to natural loss, and new space is provided for massive recruitment; for management pur- 
poses, other variables, such as seasonal variation in chemical contents, need to be considered. Studies carried out in southern Chile (Westermeier 1987, Westermeier et al. 1987) indicate high levels of alginic acid in autumn and spring for $L$. nigrescens, while $D$. antarctica has high values in summer and winter. Thus, the integration of population data with temporal chemical variation, as well as internal and external marketing demands, will make possible the development of a management scheme for the littoral areas of Chile.

Acknowledgements. This study was carried out as part of the grant 'Biology of brown algae in Chile' supported by Volkswagen Foundation, Germany. The financial support for the field work was provided by Grant RS 85-11 from Dirección de Investigación, Universidad Austral de Chile. The authors thank the students of Laboratorio de Botánica Marina (from Instituto de Botánica, Universidad Austral de Chile) for their valuable help in the field. Finally we thank D. Patiño for his helpful field assistance.

\section{LITERATURE CITED}

Aguilera, M., Rivera, P. J., Westermeier, R. (1988). Presencia de Hongos del orden Plasmodiophorales en plantas de Durvillaea antartica (Cham.) Hariot (Phaeophyceae, Durvilleales) en el Sur de Chile. Gayana bot. 45: 337-343

Bustamante, R. H., Castilla, J. C. (1990). Impact of human exploitation on populations of the intertidal southern bull kelp Durvillaea antarctica (Phaeophyta, Durvilleales) in central Chile. Biol. Cons. 52: 205-220

Castilla, J. C., Bustamante, R. H. (1989). Human exclusion from rocky intertidal of Las Cruces, central Chile: effects on Durvillaea antarctica (Phaeophyta, Durvilleales). Mar. Ecol. Prog. Ser. 50: 203-214

Cheshire, A. C., Hallam, N. D. (1988a). Biomass and density of native stands of Durvillaea potatorum (southern bull-kelp) in southeastern Australia. Mar. Ecol. Prog. Ser. 48 $277-283$

Cheshire, A. C., Hallam, N. D. (1988b). Morphology of the southern bull-kelp (Durvillaea potatorum, Durvilleales, Phaeophyta) from King Island (Bass Strait, Australia). Botanica mar. 31: 139-148

Cheshire, A. C., Hallam, N. D. (1989). Methods for assessing the age composition of native stands of subtidal macroalgae: a case study on Durvillaea potatorum. Botanica mar. 32: 199-204

Connell, J. K. (1975). Some mechanisms producing structure in natural communities: a model and evidence from field experiments. In: Cody, M. L., Diamond, J. M. (eds.) Ecology and evolution of natural communities. Belknap Press of Harvard University, Cambridge, p. 457-490

Doty, M. (1971). Measurements of water movement in reference to benthic algal growth. Botanica mar 14:32-35

Druehl, L. D., Green, J. M. (1982). Vertical distribution of intertidal seaweeds as related to pattern of submersion and emersion. Mar. Ecol. Prog. Ser. 9: 163-170

Guiler, E. R. (1959). The intertidal ecology of the Montemar area Chile. Pap. Proc. R. Soc. Tasm. 93: 165-183

Hawkins, S. J., Hartnoll, R. G. (1985). Factors determining the upper limits of intertidal canopy-forming algae. Mar. Ecol. Prog. Ser. 20: 265-271

Hay, C. H. (1977). A biological study of Durvillaea antarctica (Cham.) Hariot and D. villana Lindauer in New Zealand. Mar. Ecol. Prog. Ser. 50: 203-214

Köehl, M. A. R. (1986). Seaweeds in moving water: form and mechanical function. In: Givnish, T. J. (ed.) On the economy of plant form and function. Cambridge University Press, Cambridge, p. 603-633

Menge, G. A., Sutherland, J. P. (1976). Species diversity gradient: synthesis of the roles of predation, competition and temporal heterogeneity. Am. Nat. 110: 357-385

Munoz, M., Santelices, B. (1989). Determination of the distribution and abundance of the limpet Scurria scurra on the stipes of the kelp Lessonia nigrescens in central Chile. Mar. Ecol. Prog. Ser. 54: 277-285

Ojeda, F. P., Santelices, B. (1984). Ecological dominance of Lessonia nigrescens (Phaeophyta) in central Chile. Mar. Ecol. Prog. Ser. 19: 1-12

Santelices, B. (1981). Perspectivas de investigación en estructura y dinámica de comunidades intermareales rocosas de Chile Central. I. Cinturones de Macroalgas. Medio Ambiente 5: 175-189

Santelices, B., Castilla, J. C., Cancino, J., Schmiede, P. (1980). Comparative ecology of Lessonia nigrescens and Durvillaea antarctica (Phaeophyta) in Central Chile. Mar. Biol. 59: 119-132

Santelices, B., Ojeda, F. P. (1984) Recruitment, growth and survival of Lessonia nigrescens (Phaeophyta) at various tidal levels in exposed habitats of central Chile. Mar. Ecol. Prog. Ser. 19: 73-82

Schonbeck, M. Norton, T (1978). Factors controlling the upper limits of the fucoid algae on the shore. J. exp. mar. Biol. Ecol. 31: 303-313

Sernap (1989). Anuario estadístico de pesca. Servicio Nacional de Pesca-Chile (Sernap), Santiago

Sokal, R. R., Rohlf, F. J. (1969). Biometry. Freeman Press, San Francisco

South, G. R., Hay, C. H. (1974). Variation in morphology and standing crop in New Zealand Durvillaed antarctica (Cham.) Hariot in relation to exposure and latitude. Proc. int. Seaweed Symp. 8: 489-498

Westermeier, R. (1980). The marine seaweed of Chile's tenth region (Valdivia, Osorno, Llanquihue and Chiloé). In: Levring. T (ed.) Proc. 10th int. Seaweed Symp. Walter de Gruyter and Co., Berlin, p. 215-220

Westermeier, R. (1987). Contenidos energéticos en una macroalgas del Sur de Chile, Durvillaea antarctica (Cham.) Hariot (Phaeophyta, Fucales). In: Verreth, J. A. J., Carrillo, M., Zauny, S., Huisman, E. A. (eds.) Aquaculture Research in Latin America. Pudoc, Wageningen, $p$. $367-379$

Westermeier, R., Guaiquil, V H., Wenzel, H., Peruzzo, G. (1987). Contenidos energéticos en Lessonia nigrescens Bory en el Sur de Chile. Abstract IIl Symposium sobre algas Marinas Chilenas y I Congreso Latinoamericano de Ficología. Universidad de Concepción, Concepción, p. 106

Westermeier, R., Rivera, P. J. (1986). Caracterización ficológica del intermareal rocoso de la X Región. (Valdivia, Osorno, Llanquihue y Chiloé) y de la XII Región (Islas Diego Ramírez), Chile. In: Westermeier, R. (ed.) Actas II Congr. Nac. Algas Mar. Chilenas, Universidad Austral de Chile, Valdivia, p. 125-144 